\title{
The Rise in Teenage Pregnancy and Covid 19 Lockdown in Southern Senetorial District of Ondo State, Nigeria
}

\author{
Justina Olufunke Aruna \\ Department of Sociology, Adekunle Ajasin University, Akungba Akoko, Ondo State, Nigeria
}

\begin{abstract}
:
Teenage pregnancy has become a pest in the society. Underage girls are caught in the jumble of being put into the family way. This has become widespread in the society and has led many young ladies to early graves as a result of failed abortions and which have led many to drop out of school. During the COVID-19 pandemic period control measures like closing of schools, restriction of movement, social distancing etc. were put in place in Nigeria to curtail the spread of the virus. And this period has become very challenging for girls and women. In-depth Interviews (IDIs) were conducted with 30 respondents who have experienced unwanted pregnancies using purposive sampling technique. The major finding is that the COVID-19 pandemic period is particularly a dangerous time for teenage girls because of the state of the economy, livelihood, hunger, and health crises worldwide. Several factors like influence of peer groups, lack of sex education, idleness, financial constraints, media influence, hawking etc have been attributed to the incessant increase of adolescent pregnancy at this period. Implications are that many of these teenagers will drop out of school which could lead to low educational attainment, marital instability, low income later in life, sexually transmitted diseases or vesico vaginal fistula (VVF) during child birth, social exclusion, unemployment, high mortality rate and early child marriage. The paper recommends; appropriate counselling, abstinence promotion, contraception information, sex education and school-completion strategies etc.
\end{abstract}

Key Words: Teenage Pregnancy, Covid 19, Idleness and Sex education 


\section{Introduction}

Covid-19 is an infectious disease caused by the recently discovered corona virus. The COVID-19 virus spreads primarily through droplets of saliva or discharge from the nose when an infected person coughs or sneezes http://www.mgsmasc.ac.in/boss/upload/news/Medanta\%20\%20Your\%20Complete\%20Guide\%20on\%20Recovery\%20from\%20COVID.pdf) the virus enters the body via nose, mouth and eyes. Some recent studies suggest that that virus may be airborne and can be spread through fine infected droplets that remain suspended in the air in closed air-conditioned environments of offices, AC cabs-buses, shopping malls and theatres due to absence of cross-ventilation, even when you are not in direct contact with an infected person. The COVID 19 pandemic was confirmed by World Health Organization (WHO, 2020) on March 11th, 2020 with majority of countries having reported increasing numbers of morbidity and mortality rates.

COVID-19 came and met the world unaware, just like other countries of the world, Nigeria had to lockdown and ceased physical and socioeconomic activities for a while, which led to loss of jobs, closure of business, even religious gathering were stopped, and schools were shut down in many parts of the countries for almost seven months leaving adolescents and teens at home (Akinleye, 2021). And these underage girls are caught in the jumble of being put into the family way. Current evidence amid COVID- 19 pandemic also expresses worries about the possible growth in violence against teenagers in sub-Saharan Africa during school closures (Addae, 2020).

Teenage pregnancy is a worldwide problem with its incidence highest in Sub-Saharan Africa. The incidence in sub-Saharan Africa is 143 per 1000 compared to 20 per 1000 in Europe. Reliable data states that almost one fifth (18.8\%) of adolescents get pregnant in Africa (Geneeskd, N. T., 2003; Loaiza, E. and Liang, M., 2013; Ahinkorah , B. O, Kang, M., Perry, L., Brooks, F., and Hayen, A., (2021) 
During the Covid-19 pandemic period, many adolescents were cut off from their friends and peers in their schools, they stayed at home to do house chores all day with little or no academic activity. The privileged adolescents and teens who had access to technological tools such as phones and laptops continued learning via E-learning platforms (google classroom, zoom, television) to make the necessary adjustments, while the underprivileged Adolescent who had no access to technological tools were encouraged to learn vocational skills and trade, some eventually drop out of school to focus on these trades. After the lockdown was lifted and school resumed, classes and examinations were rushed to make up for the lost time and to meet up with the academic session (Akinleye, 2021). This made it difficult for slow learning adolescents to catch up with classes. During the lockdown, there was a sharp increase in the numbers of teenage pregnancy, all over the country, because these adolescents and teens and their sexual predators were kept within a confined space for a prolonged period of time playing around the streets and neighbourhood.

\section{Statement of the Problem}

The COVID-19 pandemic has caused unparalleled destruction on children, families and communities around the world, disturbing vital services and causing menace to millions of lives (World Vision, 2020)

The pandemic has impacted on socioeconomic, social, cultural, educational and health aspects of people's life. One of the socioeconomic impacts is early marriage and teenage pregnancy (Musa, S.S; Odey, G.O; Musa, M.K; Alhaj, S. M; Sunday, B.A; Muhammad, S.M and Lucero- Prisno, D. E, 2021). Teenage pregnancy is getting pregnant in age range of 1319 years old (United Nations Children's Fund, 2020) Teenage pregnancy is when a teenager or under-aged usually within age of thirteen to nineteen years becomes pregnant or the conception by girls between the age of 13 and 19 years.

The COVID-19 pandemic is an especially dangerous time for teenage pregnancies because of the growing economic, hunger, and health crises worldwide. According to (World Vision Zimbabwe, 2020) there has been an increased incidence of teenage pregnancies and early 
marriages in Zimbabwe and the figures have doubled since the beginning of the COVID19 lockdown. It was also noted that without the support system of teachers and school authorities, several girls were exposed to sexually transmitted infections, unwanted pregnancies and sexual exploitation among other overwhelming effects of COVID-19 (UNFPA, 2020b). A report by World Vision on COVID19 Aftershocks-Access Denied (2020) states that school cessations during crises has led to upsurges in teenage pregnancy up to about 65 per cent, as closures result in girls having more time with males than they would be if schools were open and as a result this leads to increased likelihood of involvement in risky sexual behaviour and greater risk of sexual violence and exploitation.

Nigeria has a population of about 178 million, with 22.5 per cent of the population between 10 and 19 years old. COVID-19 came and met the world unprepared, Nigeria just like other countries of the world had to lockdown and ceased physical and socioeconomic activities for a while, jobs were lost, the business closed, religious gathering stopped, and schools were shut down in many parts of the countries for almost seven months leaving adolescents at home. School closures during crises resulted in girls spending more time with men and boys than they would were they to be in school, leading to greater likelihood of engagement in risky sexual behaviour and increased risk of sexual violence and exploitation ( World Vision, 2020; Akinyele, 2021). Teenage pregnancy, also called unwanted pregnancy has become a bane in the society. Underage girls are caught in the mess of being put into the family way. This has become rampant in the society and has led many young ladies to early graves as a result of unsuccessful abortions.

There are unmet needs that have challenged teenage girls who have fallen pregnant in the COVID 19 lockdown period. Literature has shown that there has been a sudden increase in the rates of teenage pregnancies, the world over during the COVID 19 pandemic. Pregnancy in this age group is a top cause of maternal morbidity and mortality (Murewanhema, 2020).

Similarly, there was an increase in the rate of teenage pregnancy and Sexually Transmitted Infections (STI) in Nigeria. Despite limited data, some states recorded more teenage pregnancy than usual. This is due to several factors that include lack of comprehensive 
sexuality education, idleness and wanting to explore, pornography, lack of access to contraceptives, rape and sexual violence to mention but a few (Musa, S.S et.al., 2021)

For example the Ogun State government on expressed worry over the increasing rate of teenage pregnancy among school girls as a result of school closure following the outbreak of Corona virus pandemic because young individuals were out of school, they were not engaged positively, so they may end up turning to sex as recreation and that might lead to teenage pregnancies and loss of school years and life opportunities and even the risk of ending up dying from septic abortions. (Akinyele, 2021). There is no documentation on experiences of pregnant adolescent girls during this COVID19 lockdown period. Although adolescents are not vulnerable to the virus itself; however, the impact of different actions taken due to the virus on adolescents have not been considered. Therefore, this paper examines the rise in teenage pregnancy and COVID -19 lockdown in Southern Senetorial District of Ondo State, Nigeria.

\section{Literature Review}

\section{Causes of Teenage Pregnancy and COVID 19}

Research findings also showed that the prevalence rate of adolescent pregnancy is highest in the North-West region accounting for 36 percent and the lowest in the South-east and Southwest. It is also a leading cause of maternal mortality in Nigeria.

Several factors have been attributed to the incessant increase in teenage pregnancy during COVID 19 (Cute Ndlovu, C.C., Makoni, P. and Vupenyu Gundani, H. 2021). the factors include;

\section{Sexual exploitation}

During this time of COVID19 national lockdown, teenagers are coerced into indulging in sexual actions by people close to them for example relatives, neighbours, tenants and are given small tokens like money or gifts. 
Early marriage In some areas of the country due to the economic pressures brought about by the COVID19 lockdown measures some parents or guardians have decided in permitting their young girl children to marry before they reach 18 years old.

Prolonged school closures This has made the young girls idle and redundant and therefore they explore in sexual activities.

Economic stress COVID 19 lockdown measures has greatly reduced the parental income as some parents have stopped going to work especially those in informal employment and as a result families cannot sustain to have decent meals. This has pushed some teenagers to exchange sex for food.

Loss of family care due to hospitalisation or quarantine As part of the management of COVID 19 parents find themselves having been hospitalised or quarantined this has negative implications on the welfare of teenage girls in that parental care is compromised. It is at this stage that teenagers tend to be naughty and end up engaging in sexual activities which could lead to teenage pregnancy.

Lack of access to birth control The imposed movement restrictions on people in general during the COVID 19 lockdown affects teenagers in a negative way as they cannot leave homes to go to a health facility. The majority of teenage girls cannot tell their parents that they are now sexually active as a result they cannot verbalise their need for a birth control method like contraceptive pills.

Lack of sex education This is mainly enforced in schools through sexual health reproductive programmes for adolescents. When schools are closed like it was for COVID 19 lockdown, teenagers will missed this form of education despite the fact that some radio stations have such programs it is a common tendency that teenagers might be shy to listen to such information in the presence of adults at home.

Shortage of oral contraceptive tablets in some facilities in the country It is common that sometimes sexual reproductive health matters are forgotten in humanitarian crisis times and in this case health authorities were focusing more on COVID19 matters and the shortage of oral contraceptives is overlooked. 
Death of a care giver COVID 19 killing mainly adults who are parents and guardians in their families and as a result it leaves teenagers even more vulnerable to teenage pregnancy. Failure by government in implementing stringent contextualised policies That heavily punishes the perpetrators of teenage pregnancies in times of national crisis like the COVID19 lockdown.

Peer pressure: Teenagers are at a critical stage of life by nature as they encounter bodily changes. As they find themselves lonely and bored during the lockdown period they find themselves in a position whereby they engage in experimental sexual activities.

\section{Socio-Psychological consequences Teenage Pregnancy}

Pregnant teenagers in most instances suffer psychologically and socially and this results in depression and self-isolation. This comes about due the consequences of rejection by the partner, parents or guardian and this happens more if the teenager is unmarried. A lot of studies show that teenagers who fall pregnant before they reach the age of 18 are more at risk to suffer violence in a marriage or in a relationship (Wodon et al, 2017).

Teen pregnancy, often forces many girls to leave school prematurely despite the fact some countries have adopted a policy of not expelling these pregnant teenagers from school during the COVID 19 crisis, however, when this happens, it makes a negative impact on the girl's future as their education is jeopardized leading to illiteracy and a reduction in employment opportunities (Plan International, 2020).

The COVID 19 Lockdown puts a lot of teenagers at risk of further domestic violence, accompanied by a rise in anxiety and stress levels, and this leads to mental health problems like suicide ideations (Octavius et al, 2020).

Online lessons that was been seen as the only option available to ensure that children learn during this COVID19 crisis diminishes the learning loss brought about by school-closures on the other hand those in rural areas or those from poor backgrounds were unlikely able to benefit from the online lessons because of digital under development. As a result they 
continue without any form of learning and hence leading them to miss school for good as they might end up being forced into child marriages.

Additionally, the more these teenagers do not get supervision, for those with access to internet, it means that they were likely at an increased risk to cyber-bullying and end up exploring pornographic material on the internet and are exposed to global norms on sexuality and begin to question social and cultural norms that impact sexual behaviour in society. This further makes them to have loose morals and hence a rise in teenage pregnancy becomes an outcome (Cute Ndlovu, C.C., Makoni, P. and Vupenyu Gundani, H., 2021).

\section{Consequences in health of Teenage Pregnancy}

Early pregnancies amongst adolescents result in severe negative health implications on teen mothers and their children. Some studies have reported that pregnancy and delivery complications in ages 15-19 years globally are the top most causes of death in this age group, more so, this is mostly evident in developing countries and this account for about $99 \%$ of world's maternal deaths for women in the age category of 15-49 (WHO, 2020). Teenage mothers are at an increased risk for eclampsia, obstructed labour, sepsis and other infections compared to their counterparts between 20-24 years (World Vision, 2020). . Furthermore, it has been reported that about 3.9 million backyard abortions in adolescents aged 15-19 years are carried out yearly and this contributes to maternal mortality, morbidity and other complications (WHO, 2020). During this COVID 19 Lockdown it has been reported as well that abortions among these teenage girls has increased (Plan international, 2020a). Children delivered by girls below 20 years old are at a greater risk of having a birth weight below 2500g, being delivered prematurely and having complicated neonatal outcomes (WHO, 2020). COVID- 19 lockdown has an increased risk of poor nutrition to most families. Having an adequate nutrition in utero and even after delivery up to about 5 years, a child is assured of a good physical and cognitive development and this has long-lasting effects in the health status of an individual (Nyaradi et al, 2013). And they could have lasting health problems such as vesicovaginal fistula (VVF).Therefore; the economic hardships brought about by COVID19 lockdown indeed pose a health risk to adolescents and their children. 


\section{Description of the study Area}

Okitipupa is a local government area in Ondo state Nigeria and part of the Ikalespeaking nation in Ondo State with its administrative headquarters in Okitipupa town. Okiti means "hilly land". Okiti-pupa is derived from the Ikale Yoruba word okiti (hilly) and pupa (red) which became a name used by people travelling from other communities to trade in the central market of the town (Okitipupa). Okitipupa has always been the central town for the inhabitants of Ondo South senatorial district of Ondo state, comprising okitipupa, Irele, Ilaje, Ese-Odo, Odigbo and Ile-Oluji/Okeigbo local governments respectively due to the presence of basic amenities. It was a district in colonial times, before Nigeria's independence in 1960. It has a university, a specialist hospital, several private hospitals, a Magistrate court, a High court, Nigerian Police Force Area command, an Army barrack, commercial banks, a telephone exchange, and numerous primary and secondary schools. Natives of Ikale are predominantly farmers. The major cash crops are oil-palm,

rubber and cassava. They also cultivate yams, beans, okra, pepper, melon and vegetables. Staple food includes but is not limited to baked cassava, popularly known as Pupuru, yam, rice, yam flour and cassava flakes (garri) among others. Districts Under Okitipupa LGA Includes; Okitipupa, Ode-Aye, Ilutitun, Ikoya, Oloto, Iju -Odo, Erekiti, Igbotako. Erinje, Idepe, Igbesi-oloto, Iju-Oke, Omotosho,Wakajaye, Akinfosile, Batedo, Ode-Erinje, Ayeka, Igbodigo, Igodan Lisa (https://en.wikipedia.org/wiki/Okitipupa).

\section{Method of Data Collection}

In-depth Interviews (IDIs) were conducted with 30 respondents who have experienced unwanted pregnancies using purposive sampling and snowball sampling techniques. This sampling technique is informed because of the sensitive nature of the topic. And moreover, since pregnant teenagers are not scattered all over the places, any pregnant teenager the researcher meets were purposively selected and interviewed. Few selected medical personnel were also interviewed in order to generate information on the consequences of teenage 
pregnancy. Data generated from the in-depth interviews were transcribed and reported in content analysis form.

\section{Findings and Discussion}

One of the respondents that was interviewed 'Aanu' 16 years old and year one student in the Senior Secondary School- SS1, said she lives with her single mother who is selling fruits at the local market. She claims that she was sexually exploited by a young undergraduate in the community who also was also staying at home during the school closure; she said "the guy took advantage of her mother's financial struggles". He offered to help support her and used his offer of support to have sex with her, and she was equally helping him to wash plates and clothing. She said further that the major challenge is that the young man absconded after putting her in the family way. And he left the responsibility of the pregnancy to her poor mother. "Another bigger challenge I have is how the face the stigmatization and how to continue with my education”.

Another respondents, 'Adura' 16 years old, who claimed she used to dream of becoming a medical doctor, she was in SS3, she lives with her parents, who are civil servants. She narrated that "it was always boring during the long stayed at home during the covid-19 pandemics, as usual she was going out with her friends, and sometimes to see her boyfriend in the neighbourhood, and now I am pregnant. The worst is that my father had sent me to my boyfriend's house and my boyfriend is not ready to marry now. And l could not seat for my Senior Secondary School Examination (SSSE) this year. I don't know whether l can continue with my education after delivery". In further interview, she claimed that the parents of her boyfriend were ready to accept her and her pregnancy.

Furthermore, another respondents 'Ibidun' 17 years staying with her single mother and three other siblings and a fish seller, while explaining how she became pregnant during the school closure. She said she managed to write her Senior Secondary School Examination (SSSE) before the pregnancy became known but she could not write her Joint Admission Matriculation Board (JAMB) that would enable her gain admission into the university. She claimed she was sexually exploited by a young man in her neighbourhood who took 
advantage of her mother's financial struggles. He offered to help support her and used his offer of support to have sex with her during the school closures. Her fear was whether she will be able to go back to school.

Interestingly, with another respondent, 'Remi' 17 years old, she lives with her mother and stepfather she became pregnant with a 21-year-old boy in the town who is also an SSS3 student. Her dream of becoming a teacher is now uncertain - she isn't sure she can go back to school as a teenage mother, even once schools reopen after the threat of COVID-19 passes. "I really don't know what will happen with me in near future. Everything seems future is not certain now. I don't even know how I will raise the child," She said, she regrets what she did, but she realizes it is too late while crying profusely. Before the pandemic, Remi was in SSS2. When the schools were closed, and her family started to struggle from the financial impacts of the lockdown, Remi decided to help make ends meet. "During this period that they didn't go to school she used to sell roasted corn by the road in order to help increase the family's income," she explained. However, the struggle to help her family led Remi into trouble.

She said she would meet this young man whenever she finishes selling her corn. She said the guy was one of her corn customers. And he gave her twenty thousand naira (20,000.00). However, now that Remi is pregnant, and her parents are very upset with her situation. She explained further that, "When I informed my boyfriend and he asked me to induce a miscarriage, but when I was afraid and refused, he suddenly disappeared from the community for Lagos,"

Another, respondent, 'Peju', 16 years old, a Junior Secondary School JSS student staying with her parents, used to dream of becoming a nurse. But, after schools were closed in March, she quickly became pregnant and she was forced to move in with her 24-year-old boyfriend 'Kunle', an 'okada' (motor bicycle) rider in the town. According to her, "now she pregnant, her future is blurry and no longer seems as bright as she once dreamed. Now all Peju can see for her future is becoming a wife and mother. Although she claims she would like to go back to school after delivery, she doubts that it will be possible. "Everything seems to be lost now. I want to go back to school but I don't see how possible. Besides, I doubt if my partner will allow me to go back". "She said she is also ashamed of going back to school, because her 
classmates will call her 'iyawo' (wife) because of her age and situation," she said sadly. She added that," The first three months of pregnancy, were the most difficult period of her life, she said. "I often felt so weak during the past three months.

\section{Consequences of Teenage Pregnancy on the teenagers:}

On the questions that bother on consequences of teenage pregnancy, the responses of the 30 respondents interviewed, are summarised below;

All the respondents/interviewee claimed that their pregnancy will lead or be led to been drop out of school which will eventually lead to low educational attainment.

15 out the respondents were senior secondary school students and they claimed that the pregnancy would not allow them sit for their SSE examination.

Some of the adolescents/teenagers interviewed also displayed the fear that even after given birth to their babies and returned back to school, they claimed that they may likely not have marital stability. Some of them also expressed fear that "these their single mistake may lead to low income later in life and their children may likely to be low of intellectual ability".

One of the respondents openly confirmed that couple with her pregnancy, she has also contracted sexually transmitted diseases and that she equally abusing substance, because her boyfriend use to give her drug anytime she visits.

During the interview sections it was observed that some of the teenagers have Anaemia (low iron levels) which may lead to some more complicated health issues like ,low birth weight/premature birth, high blood pressure/pregnancy-induced hypertension, PIH (can lead to preeclampsia), higher rate of infant mortality (death), Possible greater risk of cephalopelvic disproportion (the baby's head is wider than the pelvic opening)and even greater implications like vesico vaginal fistula (VVF) during child birth as it was explained by the medical personnel during the interview sections. 


\section{RECOMMENDATION}

Since the problems of adolescents' pregnancy are multi-dimensional in nature, there is therefore urgent need for holistic approach in addressing this menace and supporting adolescent girls to realize their potentials.

1. The Ministry of Education in Nigeria should develop guidelines that will support teenagers with unplanned pregnancies to continue schooling or opt to return after delivery. Something like School- completion strategies and probably in job training for those who cannot complete school.

2. State and local authorities should develop stringent byelaws to enforce, prohibit and sanction perpetrators of sexual exploitation or abuse against girls.

3. Government should identify and help poverty stricken communities or families with food hand-outs to avoid girls being exploited in exchange of food during COVID19 lockdowns or any other unforeseen circumstances as the world is talking about the $3^{\text {rd }}$ face of the virus.

4. Schools, churches, Non-governmental Organisations should make appropriate counselling available for teenagers especially the female gender.

5. Government should make available, affordable and adequate healthcare services.

6. Schools and Non-governmental Organisations should make available abstinence promotion and contraception information to students across schools.

7. Government and health care providers should make contraceptive availability a main concern.

8. Sex education should be taught in schools and across local communities. 


\section{REFERENCES}

Addae E.A, (2020) COVID- 19 pandemic and adolescent health and well- being in subSaharan Africa: Who cares? The International Journal of Health Planning and Management. https://doi.org/10.1002/hpm.3059

Akinyele, A. ( 2021) Evaluating Impact of COVID-19 on Adolescents This Day

January 28, https://www.thisdaylive.com/index.php/2021/01/28/evaluating-impact-ofcovid-19-on-adolescents/ (Accessed 13 July, 2021)

Ahinkorah, B. O, Kang, M., Perry, L., Brooks, F., and Hayen, A., (2021) Prevalence of first adolescent pregnancy and its associated factors in sub-Saharan Africa: A multicountry analysis https://doi.org/10.1371/journal.pone.0246308

Cute Ndlovu, C.C., Makoni, P. and Vupenyu Gundani, H. (2021) COVID 19 lockdown related teenage pregnancy: Concept Analysis. International Journal of Advance Research in Nursing 4(1): 101-108.

Geneeskd, N. T., (2003) Teenage pregnancy, a worldwide problem ;147(47):2320-5. https://pubmed.ncbi.nlm.nih.gov/14669537/

Loaiza, E. and Liang, M., (2013) ADOLESCENT PREGNANCY: A Review of the Evidence https://www.unfpa.org/sites/default/files/pubpdf/ADOLESCENT\%20PREGNANCY_UNFPA.pdf UNFPA New York.

Medanta , (2020) Your complete guide in recovery from Covid-19 http://www.mgsmasc.ac.in/boss/upload/news/Medanta\%20\%20Your\%20Complete\%20Guide\%20on\%20Recovery\%20from\%20COVID.pdf

Murewanhema G.(2020) Adolescent girls, a forgotten population in resource-limited settings in the COVID-19 pandemic: Implications for sexual and reproductive health outcomes. The Pan African Medical Journal; 37(41):41. https://doi.org/10.11604/pamj.supp.2020.37.1.26970

Musa, S.S, (2021) Early marriage and teenage pregnancy: The unspoken consequences of COVID-19 pandemic in Nigeria. Public Health in Practice.

Volume https://www.sciencedirect.com/science/article/pii/S266653522100077X 
Nyaradi A, Li J, Hickling S, Foster J, Oddy W.H.( 2013) The role of nutrition in children's neurocognitive development, from pregnancy through childhood. Frontiers in human neuroscience 2013;7:97. https://doi.org/10.3389/fnhum.2013.00097

Ogunnaike, J. (2020) https://www.vanguardngr.com/2020/06/covid-19-ogun-raises-concernover-high-rate-of-teenage-pregnancy/ Vanguard June 17, 2020

Octavius Gilbert Sterling, Silvianil, F.R., Lesmandjaja1, A., Angelina, Juliansen, J. (2020) Impact of COVID-19 on adolescents' mental health: a systematic review Middle East Current Psychiatry 27:72 .

Plan international, (2020) Covid-19: lockdown linked to high number of unintended teen pregnancies in Kenya https://plan-international.org/news/2020-06-25-covid-19lockdown-linked-high-number-unintended-teen-pregnancies-kenya.

UNFPA. (2020)Technical brief: COVID-19 and Young Girls Vulnerability to Child Marriage and Teenage Pregnancy in Afghanistan 2020.

UNFPA Zimbabwe(2020) Lockdown with your abuser: Over $700 \mathrm{GBV}$ in 11 days . https://zimbabwe.unfpa.org/en/news/lockdown-your-abuser-over-700-gbv-11-days

United Nations Children's Fund(2020) Shared Responsibility, Global Solidarity: Responding to the Socio-economic Impacts of COVID-19 (March 2020) COVID-19: Working with and for young people 2020.

Wodon, Q, Chata M., Nayihouba, A., Onagoruwa, A., Savadogo, A. et al. (2017) Economic Impacts of Child Marriage: Global Synthesis Report 2017. 
4th International Conference on Modern Research in SOCIAL SCIENCES

\section{IOM)SS}

29-31 July, 2021

MUNICH, GERMANY

World Vision Zimbabwe, (2020) COVID-19 aftershocks and their impact on girls' education in Zimbabwe, World Vision 2020. https://www.wvi.org/sites/default/files/2020-

8/Aftershocks\%20of\%20COVID\%2019\%20on\%20girls_Final.pdf

World Vision, (2020) COVID19 After shocks 2020. https://www.wvi.org/publications/report 